\title{
ЕКОНОМІЧНИЙ ЗМІСТ ДИПЛОМАТІЇ У СВІТОВИХ ТЕНДЕНЦІЯХ ЧЕТВЕРТӦ̈ ПРОМИСЛОВОЇ РЕВОЛЮЦІї
}

У статті розкриваються питання сутності економічної дипломатії, реалізації принципів іiі політики, особливості необхідності державного регулювання та застосування інструментів антикризової політики економічної дипломатії. Проаналізовано питання зміни міжнародної конкурентоспроможності національної економіки в контексті Четвертої промислової революції. Народження нових перспектив у зв'язку 3 переоцінкою міжнародного співробітництва, спеціалізації, реформи і знаходження нових джерел коштів і нового імпульсу для світової.

У сучасних умовах, функції економічної дипломатії окреслюються розвитком i модернізацією структури світової економіки на всіх рівнях: глобальному, національному, регіональному. У міру поглиблення глобалізації дипломатичні напрямки експорту піднялися до рівня торгово-економічного, економічного управління національними інтересами за кордоном на всіх стадіях: порядок входження національних елементів в закордонну економіку, забезпечення гарантій, організація підтримки національним фірмам та окремим суб'єктам щодо розвитку та зміцнення іноземних позицій національної економіки, формування механізмів регулювання суперечок.

Ключові слова: економічна дипломатія, Четверта промислова революція, інформаційна глобалізація, безпека, світові економічні відносини.

Hrushchynska Nataliia, Doctor of Economics, Associate Professor, Diplomatic Academy of Ukraine, MFA of Ukraine, Kyiv, Ukraine

Economic meaning of diplomacy in global tendencies of Fourth Industrial Revolution

The article reveals the essence of the issue of economic diplomacy, implementing the principles of its policy, especially the need for state regulation and application of anti-crisis policytools of economic diplomacy. Analyzed the issue of changing the international competitiveness of the national economy in the context of the fourth industrial revolution. The birth of new prospects due to revaluation of international cooperation, specialization, reform and finding new sources of capital and new impetus to the world.

Key words: economic diplomacy, the Fourth Industrial Revolution, informational globalization, security, world economic relations.

Груцинская Наталья Николаевна, доктор экономических наук, доцент, Дипломатическая академия Украины при МИД Украины, Киев, Украина

\section{Экономическое содержание дипломатии в мировых тенденциях Четвертой промышленной революции}

В статье раскрываются вопросы сущности экономической дипломатии, реализации принципов ее политики, особенности необходимости государственного регулирования и применения инструментов антикризисной политики экономической дипломатии. Проанализированы вопросы изменения международной конкурентоспособности национальной экономики в контексте Четвертой промышленной революции. Рождение новых перспектив в связи с переоценкой международного сотрудничества, специализации, реформы и нахождения новых источников средств и новый импульс для мировой. В современных условиях, функции 
экономической дипломатии определяются развитием и модернизацией структуры мировой экономики на всех уровнях: глобальном, национальном, региональном. По мере углубления глобализации дипломатические направления экспорта поднялись до уровня торговоэкономического, экономического управления национальными интересами за рубежом на всех стадиях: порядок вхождения национальных элементов в зарубежную экономику, обеспечение гарантий, организация поддержки национальным фирмам и отдельным субъектам по развитию и укреплению иностранных позиций национальной экономики, формирования механизмов регулирования споров.

Ключевые слова: экономическая дипломатия, Четвертая промышленная революция, информационная глобализация, безопасность, мировые экономические отношения.

Вступ. Четверта промислова революція триває в усьому світі, зокрема і в Україні та передбачає пріоритет інформаційних технологій, перехід до цифрової економіки, що $є$ необхідними умовами розвитку і виживання українського бізнесу в умовах суворої конкуренції на світових ринках. Четверта промислова революція передбачає розвиток і злиття автоматизованого виробництва, обміну даних і виробничих технологій в єдину саморегульовану систему, 3 якнайменшим або взагалі відсутнім втручанням людини у виробничий процес. Фаза промислової революції, яка характеризується злиттям технологій, що розмиває межі між фізичною, цифровою та біологічною сферами в контексті розвитку кіберпростору, інформаційної безпеки країни. Реалізація принципів промислової революції в усіх сферах життєдіяльності обумовлюється також і зовнішніми зносинами країн, продиктованих, насамперед, процесами глокалізації, геополітичними та геоекономічними тенденціями. У зазначеному ракурсі економічна дипломатія визначає інструменти, які є допомогою розвитку співпраці країн та їх ефективній взаємодії в контексті четвертої промислової революції.

Аналіз використаних джерел. У зарубіжних та вітчизняних джерелах недостатньо розкриваються проблеми взаємозв'язку політики та дипломатії, економізації зовнішньої політики як засобу розвитку співробітництва між державами, простежується відсутність комплексного підходу до освітлення проблем економічної дипломатії в контексті геоекономічних та геополітичних процесів національної економіки, що вимагає активізувати дослідження даної проблематики, особливо з умовах змін світової економіки та визначення місця країн у світових процесах, загалом.

Серед американських політологів і теоретиків міжнародних відносин заслуговують на увагу дослідження дипломатів У. Бернса, А. Вершбоу, М. Стирна, Р. А.Уолкера, А. Эбана; британські дипломати Р. Барстон, Дж. Берридж, Дж. Кауфман, Г. Никольсон, Э. Сатоу та ін. Теоретичну основу статті становлять роботи провідних вітчизняних і закордонних учених $\mathrm{i}$ фахівців у сфері процесів конкурентоспроможності національної економіки, геоекономіки, геополітики, міжнародних процесів формування світового економічного порядку, таких як В. А. Вергун, Т. В. Зонова, В. М. Нижник, Р. Каган, О. Коппель, О. М. Шаров, А. Уткін, К. А. Фліссак.

Дослідженням питань четвертої промислової революції та в контексті цього застосування інклюзивної моделі економічного розвитку країни присвячені праці переважно закордонних вчених: Д. Асмоглоу [10], Е. С. Райнета, Дж. Подеста [13]. Серед українських науковців можна виділити наукові праці С. С. Кожемякіної [12], О. Карп’юк [11].

Мета статті полягає у розкритті особливостей економічної дипломатії як політики антикризового направлення з урахуванням геополітичних і геоекономічних світових процесів у контексті тенденцій Четвертої промислової революції.

Викладення основного матеріалу. Можливості розвитку та визначення місця в глокалізаційному світі для України полягають у наступних аспектах: інноваційний продукт потребує виходу на світовий ринок. Сучасна промислова автоматизація все більше стає ITPowered Automation. Необхідним $є$ отримання досвіду у зарубіжних виробників щодо 
використання передових технологій, інформування світу про свої вміння і знання, оутсорсинг проектування і монтажу, субпідряди, готовність до роботи на об'єктах по всьому світу; створення платформи для обміну інформацією щодо спеціалістів, проектів, досвіду для продажу своїх послуг світу; внутрішні стандарти необхідно адаптувати до міжнародних стандартами; проведення об'єднання бізнесу.

До 2020 р. наслідки Четвертої промислової революції відкриють людині світ робототехніки та автономного транспорту, штучного інтелекту та навчання за допомогою машин, нових матеріалів, біотехнологій і геноміки.

Відомий швейцарський економіст доктор Клаус Шваб, засновник і керівник Всесвітнього економічного форуму, наголошує: «Четверта революція йде на нас, як цунамі! Швидкість цієї революції така висока, що політичній спільноті важко або навіть неможливо встигати 3 необхідними нормативними та законодавчими рамками». Він також вважає: «Ця революція кардинально змінить те, як ми живемо, працюємо, ставимося один до одного. Подібного масштабу і складності змін людству ще ніколи не доводилося відчувати. Уже зараз очевидно, що вона торкнеться всіх груп, шарів і прошарків людства і всіх професій».

Найсильнішими факторами впливу на глобальну економіку є поширення Інтернету, мобільного зв'язку, автоматизація рутинної інтелектуальної роботи; хмарні технології та рішення по зберіганню енергії; наступні покоління підходів до управління геномами; просунута

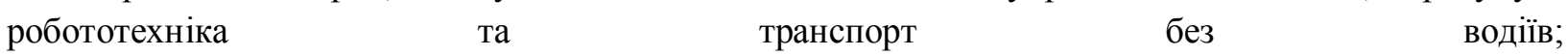
3D-друк і т. ін. Відповідно, такі процеси сприятимуть знищенню професій, які не потребують високої кваліфікації.

В основі розвитку конкурентоспроможності товару, країни, підприємства покладені теорії міжнародної торгівлі, одна 3 яких теорія життєвого циклу продукції. Лише для управління системою іiі можна трактувати наступним чином: у залежності від стану розвитку суспільна на першому етапі розвитку (1-й рівень зрілості суспільства) основна увага приділяється продукції, а точніше, питанням безпеки продукції (послуг). Для вирішення проблеми застосовуються засоби технічного регулювання, обов'язкові для всіх суб'єктів товарно-грошових відносин. На другому етапі (2-й рівень зрілості) основним об'єктом уваги залишається та сама продукція, але акцент переноситься вже на якість, тобто ії споживчі властивості. Тут нормативною основою є стандарти, які мають добровільний характер. На третьому етапі (3-й рівень зрілості) значну увагу починають приділяти вже організаціям, удосконаленню їхніх локальних цільових систем менеджменту, перш за все, менеджменту якості, на основі вимог стандартів на ці системи. I, нарешті, на четвертому етапі при досягненні найвищого рівня розвитку (4-й рівень зрілості) головна увага організацій приділяється вже цілісним системам менеджменту. Основний акцент робиться на яскраво вираженому соціально відповідальному ставленні до всіх зацікавлених сторін і цілеспрямованому системному вдосконаленню всіх аспектів діяльності. При цьому що вищий рівень ділової досконалості організації, то вища якість продукції. Поліпшуються також інші показники: продуктивність праці, собівартість продукції, вплив на довкілля, задоволеність персоналу тощо.

Під впливом Всесвітнього економічного форуму 2016 р. технології 4.0 стали популярними в контексті розвитку IT, бізнес-школ. Водночас, 99 \% гравців ринку промислової автоматизації, навіть великі міжнародні бренди, присутні в Україні, не розкривають свою роботу в контексті трендів четвертої промислової революції. Нині, модернізація української промисловості $\epsilon$ питанням уже не для обговорення, а для конкретних дій та висновків, нагальним $є$ об'єднання 3 IT-сектором, іншими хай-тек спільнотами та спільне спрямування загального руху на прискорену модернізацію української промисловості, масово та швидко впроваджуючи нові технології 4.0.

В умовах глобальної конкуренції сучасні країни використовують широкий арсенал інструментів і методів економічної дипломатії для захисту національних інтересів. Актуальність використання коштів економічної дипломатії відображає конструктивний характер взаємодії країн у двосторонніх і багатосторонніх торгових відносинах. Економічна дипломатія спрямована на 
виконання цілей і завдань торговельної політики, захисту внутрішнього ринку від кризових впливів у світовій економіці, особливо жорсткою іноземної конкуренції, різкого зростання імпорту та ін. несприятливих умов для розвитку національної економіки, а також захисту прав і економічних інтересів вітчизняних підприємств та ін. суб'єктів господарювання за кордоном. Покликання дипломатії - забезпечення національної безпеки держави шляхом ведення переговорів. Іншими словами, певна антикризова політика для зменшення або скасування гострих кутів у співпраці двох або більше сторін. Економічна дипломатія - це особливий фундаментальний антикризовий інструмент, тому що спрямована саме на економічні інтереси країни. Прикладом може бути введення економічних санкцій і відповідна реакція на них, яка призводить до їх скасування, зменшення або збільшення.

Забезпечення національних інтересів та захист національної безпеки залишаються пріоритетним завданням економічної дипломатії; вони органічно включають в себе позиції своїх національних чинників на світовому ринку, що розширюється. Основними для економічної дипломатії стають поняття поєднання національного виробництва, традицій, національних пріоритетів. Економічна дипломатія не тільки допомагає вирішенню поточних і орієнтованих на найближче майбутнє завдань, але також впливає на характер оцінок навіть віддалених суспільноекономічних перспектив.

У сучасних умовах у дипломатії України формуються багатосторонній характер i економічна дипломатія набуває креативних форм реалізації. Традиційні форми реалізації дипломатії із застосуванням креативних, нетрадиційних форм є запорукою успіху і розвитку.

У нових умовах прояву креативних форм дипломатії, створюють передумови для ін. підходів до вирішення завдань, які ставляться перед економічною дипломатією. Рішення даних проблем вимагає інформаційного, інноваційного, культурного та ін. підстав для застосування антикризових дій.

Реалізація принципів економічної дипломатії пов'язано зі здійсненням торговельної політики держави, питання антикризової функції економічної дипломатії набуває особливої актуальності. Кризові процеси обумовлюються різким загострення суперечностей, які виникають у процесі взаємодії окремих суб'єктів світогосподарських зв'язків. Покликання дипломатії забезпечення національної безпеки держави шляхом ведення переговорів. Іншими словами, певна антикризова політика для зменшення або скасування гострих кутів у співпраці двох або більше сторін. Економічна дипломатія - це особливий фундаментальний антикризовий інструмент. Яскравими прикладами, можуть бути введення економічних санкцій і відповідна реакція на них, яка може призводити до їх скасування, зменшення або збільшення.

Антикризові процеси з боку держави здійснюються шляхом використання інструментів організаційно-економічного, нормативно-правового впливу, які направлені на захист суб'єктів національного ринку від кризових явищ.

Нині функції економічної дипломатії обумовлюються, в першу чергу, розвитком i модернізацією структури світової економіки на всіх рівнях: глобальному, національному, регіональному. Тобто відбувається розширення числа країн-учасниць. У міру поглиблення глобалізації дипломатичне спрямування експорту піднялося до рівня торгово-економічного або економічного управління національними інтересами за кордоном на всіх стадіях: порядок входження національних факторів у закордонну економіку, забезпечення гарантій, організація підтримки національним фірмам і окремим обличчям у діяльності з розвитку і зміцнення закордонних позицій національної економіки, формування механізмів дозволу суперечок.

Висновки. Забезпечення національного інтересу i захист національної безпеки залишаються пріоритетним завданням економічної дипломатії; вони органічно містять у собі позиції своїх національних факторів на світовому ринку, що розширюється. Важливого значення набуває здатність економічної дипломатії працювати в режимі, що випереджає, забезпечувати політичний заділ для просування економічних інтересів. Основними для економічної дипломатії стають поняття поєднання національного виробництва, традицій, національних пріоритетів. 
Економічна дипломатія не тільки допомагає вирішенню поточних і орієнтованих на найближче майбутнє завдань, але також впливає на характер оцінок навіть віддалених суспільно-економічних перспектив. Економічна дипломатія набуває особливих форм прояву. У сучасних умовах у дипломатії України формується багатосторонній характер і креативні форми реалізації, що $€$ необхідною умовою визначення країни в сучасних світових трансформаційних умовах.

\section{Список використаних джерел:}

1. Баранай П. Современная экономическая дипломатия [Электронный ресурс] / П. Баранай, Н. Филини. - Режим доступа: [http://www.proza.ru/2010/10/30/706]. - Загл. с экрана. Дата обращения 13.02.2017.

2. Вергун В. А. Економічна дипломатія в системі чинників міжнародної конкурентоспроможності України / В. А. Вергун // Актуальні проблеми міжнародних відносин. 2008. - Ч. 1, № 74. - С. 150-154.

3. Зонова Т. В. Экономическая дипломатия [Электронный ресурс] / Т. В. Зонова // Внешнеэкономические связи. - 2006. - № 1. - С. 14-16. - Режим доступа: [http://www.ng.ru/energy/2008-06-10/20_azerbaijan.html]. - Назва з екрану. - Дата звернення 25.01.2017.

4. Каррон де ла Каррьер Г. Экономическая дипломатия. Дипломат и рынок / Каррон де ла Каррьер Г. - Москва: Росспэн, 2003. - С. 27.

5. Мамалига О. О. Трансформація економічної дипломатії в міжнародних економічних відносинах / О. О. Мамалига. // Проблеми і перспективи розвитку підприємництва. - 2015. - № 3. C. $80-84$.

6. Нижник В. М. Економічна дипломатія та економічна безпека України: навч. посіб. / В. М. Нижник. - Хмельницький: ХНУ, 2007. - 299 с.

7. Фліссак К. А. Економічна дипломатія: навч. посіб. / К. А. Фліссак. - Тернопіль: Новий колір, 2013. - $440 \mathrm{c}$.

8. Шаров О. М. Щодо шляхів вдосконалення організації роботи в галузі економічної дипломатії: стратегічні аспекти [Електронний ресурс]: аналітична записка / О. М. Шаров // Нац. інт стратег. дослідж. - Режим доступу: http://www.niss.gov.ua/ articles/975/. - Назва з екрану. - Дата звернення 03.02.2017.

9. Шевченко Б. И. Экономическая дипломатия в современной системе международных отношений / Б. И. Шевченко // Экономический журнал. - 2016. - № 5 (41). - С. 29-41.

10. Acemoglu D. Why nations fail: the origins of power, prosperity, and poverty. Why Nations Fail, Crown Business / D. Acemoglu, James A. Robinson. - 1st ed., 2012.

11. Karp'yuk O. National models stimulate the innovation process / O. Karp'yuk // The strategic priorities. - 2013. - № 3. - C. 47-49.

12. Kozhemyakina S. M. Increased productivity as the basis for economic growth in Ukraine / S. M. Kozhemyakin // Economy of Ukraine: Ukrainian reform innovation strategy [collective monograph: Ed. V. F. Besedin, A. S. Muzychenko]. - Ktiv: NDEI, 2010. - C. 83-91.

13. Podesta J. Inclusive Economic Growth [Electronic resource]: Increasing Connectivity, Expanding Opportunity, and Reducing Vulnerability / J. Podesta // Mode of access: https://www.americanprogress.org/issues/economy/report/2013/02/07. - . Last access: 20.02.2017. Title from the screen.

\section{References:}

1. Baranai, P., Filini, N. (2013). Modern economic diplomacy. [online] Available at: http://www.proza.ru/2010/10/30/706. [Accessed 13 February 2017]. Title from the screen. 
2. Verhun, V.A. (2008). Economical diplomacy in the system of foreign economic competitiveness of Ukraine. Aktualni problemy mizhnarodnykh vidnosyn [Current problems of international news], no. 74, part 1, pp. 150-154.

3. Zonova, T.V. (2006). Economic Diplomacy. Vneshneekonomicheskie sviazi [Foreign economic relations], no. 1, pp. 14-16, [online] Available at: http://www.ng.ru/energy/2008-0610/20_azerbaijan.html. [Accessed 13 February 2017]. Title from the screen.

4. Karron de la Karrer, G. (2003). Economic diplomacy. Diplomat and market. Moscow: Rosspen.

5. Mamalyha, O.O. (2015). Transformation of economical diplomacy in international economics. Problemy $i$ perspektyvy rozvytku pidpryiemnytstva [Problems and perspectives of development of enterprises], no. 3(1), pp. 80-84.

6. Nyzhnyk, V.M. (2007). Economical diplomacy and economical security of Ukraine. Khmelnytskyi: HNU.

7. Flissak, K.A. (2013). Economical diplomacy. Ternopil: Novyi kolir.

8. Sharov, O. M. On ways to improve the organization of work in the field of economic diplomacy: strategic aspects. Analytical note. National Institute for Strategic Studies [online]. Available at: http://www.niss.gov.ua/ articles/975/. [Accessed 03 February 2017]. Title from the screen.

9. Shevchenko, B.I. (2016). Economic diplomacy in the modern system of international relations. Ekonomicheskii zhurnal [Economic Journal], no. 5 (41), pp. 29-41.

10. Acemoglu, D. (2012). Why nations fail: the origins of power, prosperity, and poverty. 1st ed. Crown Business.

11. Karpyuk, O. (2013). National models stimulate the innovation process. The strategic priorities, no. № 3, pp. 47-49.

12. Kozhemyakina, S.M. (2010). Increased productivity as the basis for economic growth in Ukraine. Economy of Ukraine: Ukrainian reform innovation strategy. Kyiv: NDEI, pp. 83-91.

13. Podesta, J. (2013). Inclusive Economic Growth: Increasing Connectivity, Expanding Opportunity, and Reducing Vulnerability. [online] Availiable at: https://www.americanprogress.org/issues/economy/report/2013/02/07. [Accessed 20 February 2017]. Title from the screen.

(C) Грущинська Н. М., 2018 